Article

\title{
The Influence of Different Pre-Treatments on the Quality and Nutritional Characteristics in Dried Undersized Yellow Kiwifruit
}

\author{
Cinzia Mannozzi ${ }^{1}{ }^{\oplus}$, Urszula Tylewicz ${ }^{2} *{ }^{\circledR}$, Silvia Tappi ${ }^{2}$, Marco Dalla Rosa $^{2}{ }^{\circledR}$, \\ Pietro Rocculi ${ }^{2}$ (i) and Santina Romani ${ }^{2}$ (D) \\ 1 Department of Agricultural, Food and Environmental Sciences, Università Politecnica delle Marche, \\ Via Brecce Bianche 10, 60131 Ancona, Italy; c.mannozzi@staff.univpm.it \\ 2 Department of Agricultural and Food Sciences, Alma Mater Studiorum, University of Bologna, \\ Piazza Goidanich 60, 47521 Cesena, Italy; silvia.tappi2@unibo.it (S.T.); marco.dallarosa@unibo.it (M.D.R.); \\ pietro.rocculi3@unibo.it (P.R.); santina.romani2@unibo.it (S.R.) \\ * Correspondence: urszula.tylewicz@unibo.it; Tel.: +39-0547-338-103
}

Received: 31 October 2020; Accepted: 22 November 2020; Published: 26 November 2020

check for updates

Featured Application: Industrial application of the pre-treatments used prior to convective drying should take into account the time required for the pre-treatments themselves. In the case of osmotic dehydration (OD), the processing time could be relatively long (up to 120-150 $\mathrm{min}$ to reach a pseudo-equilibrium of the mass change), but it offers the possibility to handle underripe and very sour fruits and it could be carried out in batch or continuous lines with fair simple technologies. Moreover, it can be performed at near ambient temperature before drying to bring the partially dewatered products to the convective drying. The spent solution management can also be easily performed. On the other hand, the industrialization of PEF pre-treatment can be easily introduced also in a continuous process since the required time for PEF application is very short (in the present work-10 s) and nowadays there are several equipment suppliers able to scale-up industrial plants from laboratory scale.

\begin{abstract}
Undersized kiwifruits are considered waste; therefore, there is a need to develop sustainable processing technologies for their valorization, in order to have a positive economic impact on their entire production chain. Therefore, the aim of this study was to apply pulsed electric fields (PEF) combined with osmotic dehydration (OD) and air drying (AD) to develop a novel yellow kiwifruit dried snack with high nutritional functionality. In particular, the effect of the different pre-treatments, PEF $(200 \mathrm{~V} / \mathrm{cm})$ and/or OD (trehalose at $40 \%)$, on the color, bioactive compounds content and antioxidant activity (AA) was evaluated on kiwifruit chips air-dried at three different temperatures $\left(50,60,70{ }^{\circ} \mathrm{C}\right)$. The results showed that better color maintenance was observed at the drying temperature of $60{ }^{\circ} \mathrm{C}$. Concerning the bioactive compounds, a good retention in total polyphenols (TP), vitamin C content and AA with the DPPH method was obtained on OD and PEF kiwifruit dried snacks, similar to that of control samples. Instead, the ABTS method showed the best AA in PEF and OD/PEF samples. In general, a shorter drying time in the OD- and PEF-treated samples could contribute to the higher sustainability of the process.
\end{abstract}

Keywords: emerging technologies; pulsed electric field—PEF; osmotic dehydration-OD; fruit snack; waste valorization 


\section{Introduction}

Nowadays, owing to the growing consciousness of environmental pollution and the high amount of produced waste during conventional food processing, consumers appreciate sustainable food productions [1]. The improvement and/or removal of one of the conventional technological steps applied in food processing can be a promising strategy in order to increase the environmental benefits and the raw material processing efficiency [2]. Moreover, consumers are increasingly interested in food products with improved safety, as well as healthy and nutritional aspects [3].

The changes in consumer perception and the need to produce safe and high-quality foods are responsible for the evolution of the established food processes or the development of new ones. Wastage arises in particular from fruit and vegetable processing or from fruits with unfitting characteristics, in terms of size and shape [4]. Since most of these products are not used for fresh consumption, they may be inappropriately disposed of, causing environmental issues. Consequently, the opportunity to reuse industrial loss and/or waste by improving process profits and sustainability is of great relevance.

According to the European Commission [5], the weight of kiwifruit must be above $65 \mathrm{~g}$, otherwise they are considered not adequate for the commercial sale and the distribution channel, thus fruitless. However, those fruits could be valorized as raw material for the production of snacks by reducing food waste and increasing their added value. Kiwifruit is a good source of antioxidant compounds such as vitamin $C$ and polyphenols, which contribute to its high antioxidant potential [6].

Commonly, freeze-drying or conventional drying have been used to obtain stable fruit products; however, these techniques present limitations such as high energy consumption and long drying times [7-9]. Moreover, drying at elevated temperatures causes irreversible damage owing firstly to the changes in cell wall and cell membrane structures that are followed by changes in the functionality of nutritious components (vitamin C, antioxidants), mainly due to oxidation [9].

In general, drying processes consume an appreciable part of the total energy used in the food industry, so it is very important to develop new hybrid drying technologies both for energy saving and preservation of the final food quality [10]. Pulsed electric field (PEF) and osmotic dehydration (OD) treatments can be used in combination owing to their modulation of specific structural features of plant tissue, enhancing the nutritional functionality of the final product [11,12]. The PEF treatment at high and moderate fields has been suggested to enhance the maintenance of nutritional components during mass transfer processes in different types of fruit [13-16], while OD treatments have been used for the retention of flavor, color, texture and inhibition of enzymatic browning [17].

In this direction, this research work was aimed at developing a novel fruit snack for the valorization of undersized kiwifruit, assessing different sustainable processing solutions. Two non-thermal technologies, such as OD and PEF as a pre-processing step to drying, were applied alone or in combination, resulting in a novel dried kiwifruit product with a short processing time and good quality, in terms of color and nutritional characteristics (antioxidant activity, total polyphenol and vitamin C content) retention.

\section{Materials and Methods}

\subsection{Sample Preparation}

Undersized kiwifruits Actinidia chinensis cv "Jintao" (average weight of $60.7 \pm 1.6 \mathrm{~g}, 13 \pm 1{ }^{\circ}$ Brix) were obtained from the Jingold Consortium (Cesena, Italy). Fruits were stored at $4 \pm 1{ }^{\circ} \mathrm{C}$ until they were used, for a period not longer than one week. Fruits were washed, peeled and sliced in order to obtain discs of $3 \mathrm{~mm}$ thick.

Kiwifruit discs were subjected to the OD process and/or PEF treatment with different combinations, selected on the basis of preliminary experiments, as reported in Table 1. Different sequences of the combined treatment were applied such as OD followed by PEF, PEF followed by OD or PEF followed by OD and again PEF treatment, in order to clearly understand the differences in terms of treatment effect through the different work sequences applied on the food product. OD was caried out in $40 \%$ $(w / w)$ trehalose solution at $35^{\circ} \mathrm{C}$ for $2.5 \mathrm{~h}$, showing a good efficiency of the process, reflected in a 
high water loss/solid gain ratio in the range of 3.5-3.6.Trehalose was chosen because of its potential positive effect in the preservation of biomolecules and low cariogenic potential when compared to sucrose $[18,19]$. The treatment was performed in continuous stirring using a fruit/OD solution ratio of 1:4, in order to avoid concentration changes of the solution during the treatment [11].

PEF treatment was applied by using a pulse generator, S-P7500 60A $8 \mathrm{kV}$ (Alintel srl., Bologna, Italy). The following process parameters were used: electric field strength of $200 \mathrm{~V} / \mathrm{cm}$, and 1000 nearrectangular-shaped pulses, with a fixed pulse width of $10 \mu$ s and a frequency of $100 \mathrm{~Hz}$. The total treatment time was set to $10 \mathrm{~s}$ and total energy input was of $1.92 \mathrm{~kJ} / \mathrm{kg}$. Table 1 summarizes the pre-treatment applied and the samples obtained at each drying temperature.

Table 1. Overview of the combination of treatments applied for kiwifruit slices at each drying temperature $\left(50,60\right.$ and $\left.70{ }^{\circ} \mathrm{C}\right)$ and relative sample codes.

\begin{tabular}{cc}
\hline Treatment & Sample Code \\
\hline Untreated & $\mathrm{C}$ \\
OD & OD \\
PEF & PEF \\
OD + PEF & OD/PEF \\
PEF + OD & PEF/OD \\
PEF + OD + PEF & PEF/OD/PEF \\
\hline
\end{tabular}

The differently pre-treated samples were subjected to air drying at 50,60 and $70{ }^{\circ} \mathrm{C}$, until a target water activity of 0.2 was reached. The drying was performed in a tray drier, CLW 750 TOP+ (Pol-Eko-Aparatura SP.J., Wodzisław Ślaski, Poland), with transverse air flow, air velocity of $2 \mathrm{~m} / \mathrm{s}$ and an air renewal fee of $50 \%$.

The total time of the drying processes varied as a function of the applied pre-treatment and temperature, as reported in Table 2.

Table 2. Total drying time ( $\mathrm{min}$ ) of the differently pre-treated kiwifruit slices at the different temperatures $\left(50,60\right.$ and $\left.70^{\circ} \mathrm{C}\right)$.

\begin{tabular}{ccccccc}
\hline $\begin{array}{c}\text { Drying } \\
\text { Temperature }\left[{ }^{\circ} \mathrm{C}\right]\end{array}$ & \multicolumn{5}{c}{ Drying Time [min] } \\
\hline & C & OD & PEF & PEF/OD & OD/PEF & PEF/OD/PEF \\
\hline $\mathbf{5 0}$ & 960 & 360 & 300 & 360 & 300 & 300 \\
$\mathbf{6 0}$ & 480 & 300 & 240 & 360 & 300 & 270 \\
$\mathbf{7 0}$ & 420 & 240 & 180 & 300 & 210 & 210 \\
\hline
\end{tabular}

\subsection{Physico-Chemical Analysis}

\subsubsection{Water Activity}

Water activity $\left(\mathrm{a}_{\mathrm{w}}\right)$ was measured with a water activity meter, AquaLab Series 3TE (Decagon Devices, Inc., Pullman, WA, USA), at room temperature. The measurements were conducted in triplicate.

\subsubsection{Color}

Instrumental color was measured using a spectrophotocolorimeter, HUNTERLAB ColorFlexTM, mod. A60-1010-615 (Reston, VA, USA). For each sample, $\mathrm{L}^{*}, \mathrm{a}^{*}$ and $\mathrm{b}^{*}$ parameters from the CIELAB scale were measured.

Results were expressed as luminosity $\left(L^{*}\right)$, hue angle $\left(h^{\circ}\right)$ and chroma $\left(C^{*}\right)$. The latter two color parameters were calculated using Equations (1) and (2), respectively:

$$
\mathrm{h}^{\circ}=\left[\operatorname{arctg}\left(\mathrm{b}^{*} / \mathrm{a}^{*}\right) 2 \pi\right] 360
$$




$$
C^{*}=\sqrt{\left(a^{* 2}+b^{* 2}\right)}
$$

where: $\mathrm{a}^{*}$ (red-green) and $\mathrm{b}^{*}$ (yellow-blue) are parameters of the color measurement.

The analyses were carried out at least in ten repetitions from each sample at each drying temperature.

\subsection{Functional Components Content and Antioxidant Activity}

The extraction was performed by mixing $0.5 \mathrm{~g}$ of dried kiwifruit sample with $10 \mathrm{~mL}$ of methanol $60 \%(w / w)$ in a centrifuge tube. The mixture was vortexed for $2 \mathrm{~min}$, agitated for $10 \mathrm{~min}$ and centrifuged for $10 \mathrm{~min}$ at $18,600 \mathrm{rpm}$ in a centrifuge (Beckman, Brea, CA, USA) set at $4{ }^{\circ} \mathrm{C}$ [20]. The supernatants were collected and used to evaluate the total polyphenol, vitamin $C$ and antiradical activity by DPPH and ABTS assays.

\subsubsection{Total Polyphenols (TP)}

The total polyphenol content (TPC) of kiwifruit samples was determined according to the Folin-Ciocalteu method, as described by Tylewicz et al. [20]. The TP content was expressed as mg of gallic acid equivalents (GAE) per $100 \mathrm{~g}$ of dried sample based on the standard curve obtained with gallic acid $\left(R^{2}=0.993\right)$. The values provided are the average of three replicates from each sample at each drying temperature.

\subsubsection{Vitamin C Content}

The determination of vitamin $C$ concentration was carried out by a redox titration using iodine solution $(0.005 \mathrm{~mol} / \mathrm{L})$. As the iodine was added during the titration, the ascorbic acid was oxidized to dehydroascorbic acid, while the iodine was reduced to iodine ions. Due to that, when all the ascorbic acid was oxidized, the excess iodine was free to react with the starch indicator by forming the blue starch-iodine complex that represent the endpoint of the titration [21]. Vitamin C content of the air-dried kiwifruit slices was expressed as $\mathrm{mg}$ of ascorbic acid per $100 \mathrm{~g}$ of dry matter of kiwifruit. The values provided are the average of three replicates from each sample at each drying temperature.

\subsubsection{Antioxidant Activity (DPPH and ABTS Assay)}

The DPPH scavenging activity was based on the method proposed by Amarowicz et al. [22]. Briefly, $0.1 \mathrm{~mL}$ of kiwifruit extract was added to $2 \mathrm{~mL}$ of methanol and $0.25 \mathrm{~mL}$ of DPPH (Sigma-Aldrich, St. Louis, MO, USA), shaken with a vortex for $1 \mathrm{~min}$ and kept in the dark for $30 \mathrm{~min}$. The absorbance was measured with a spectrophotometer (Beckman Coulter DU 730 Life Science model) at $517 \mathrm{~nm}$. Antioxidant activity was quantified by Trolox (Sigma-Aldrich, Milan, Italy) as an external standard. The results were expressed as $\mu \mathrm{mol}$ Trolox $/ 100 \mathrm{~g}$ of dry matter of fruit.

The ABTS+• scavenging activity was carried out following the method proposed by Re et al. [23]. Here, $30 \mu \mathrm{L}$ of extract was added to $3 \mathrm{~mL}$ of diluted ABTS+• solution (Sigma-Aldrich, St. Louis, MO, USA) after mixing and the absorbance was measured with a spectrophotometer (Beckman Coulter DU 730 Life Science model) at $734 \mathrm{~nm}$ every $30 \mathrm{~s}$ for a total time of $6 \mathrm{~min}$; the results were expressed as $\mu \mathrm{mol}$ Trolox/100 g of dry matter of fruit. Antioxidant activity was quantified based on the standard curve obtained with Trolox (Sigma-Aldrich, Milan, Italy). The values provided are the average of three replicates from each sample at each drying temperature.

\subsection{Statistical Analysis}

All obtained data were evaluated and discerned by using an analysis of variance (ANOVA) followed by Tukey's HSD post hoc test to compare the means at the level of confidence of $95 \%(p<0.05)$. The analysis was performed using the software STATISTICA 6.0 (Statsoft Inc., Tulsa, UK). 


\section{Results}

\subsection{Color}

Fresh kiwifruit samples were characterized by $\mathrm{L}^{*}, \mathrm{~h}^{\circ}$ and $\mathrm{C}^{*}$ color parameter values equal to $43.8 \pm 3.1,88.4 \pm 1.2$ and $23.9 \pm 1.9$, respectively, while the color parameters of dried kiwifruit snacks are reported in Table 3. As it can be seen from Table 3, the different pre-treatments had an influence on the final color of the kiwifruit snacks. The pre-treatment with OD and PEF alone did not promote any changes in color parameters in samples dried at three different temperature, while a decrease in the luminosity of the samples pre-treated with the combination of OD/PEF and PEF/OD was observed. Concerning the hue $\left(\mathrm{h}^{\circ}\right)$ angle color parameter, no significant differences were found between the different samples, while the chroma parameter $\left(C^{*}\right)$ was found to decrease in the OD/PEF and PEF/OD samples dried at the lowest and highest temperatures. In general, the drying temperature of $60{ }^{\circ} \mathrm{C}$ seems to be the most suitable for the maintenance of the kiwifruit fresh-like color.

Table 3. Color parameters ( $\mathrm{L}^{*}$-luminosity, $\mathrm{h}^{\circ}$ - hue angle, $\mathrm{C}^{*}$ - chroma) of untreated and differently pre-treated kiwifruit snacks dried at the temperatures of 50,60 and $70{ }^{\circ} \mathrm{C}$.

\begin{tabular}{|c|c|c|c|c|c|c|}
\hline & $\mathrm{C}$ & OD & PEF & $\mathrm{OD} / \mathrm{PEF}$ & PEF/OD & PEF/OD/PEF \\
\hline \multicolumn{7}{|c|}{$50^{\circ} \mathrm{C}$} \\
\hline$L^{*}$ & $47.1 \pm 2.1^{\mathrm{aA}}$ & $45.1 \pm 4.0^{\mathrm{aA}}$ & $43.9 \pm 2.3^{\mathrm{aA}}$ & $39.9 \pm 4.5^{\mathrm{abA}}$ & $38.7 \pm 3.7^{\mathrm{bAB}}$ & $42.9 \pm 3.2^{\mathrm{aA}}$ \\
\hline $\mathbf{h}^{\circ}$ & $79.1 \pm 1.8^{\mathrm{aA}}$ & $80.4 \pm 1.5^{\mathrm{aA}}$ & $78.3 \pm 2.1^{\mathrm{aA}}$ & $77.9 \pm 2.1^{\mathrm{aA}}$ & $77.7 \pm 1.9^{\mathrm{aA}}$ & $77.9 \pm 1.9 \mathrm{aA}$ \\
\hline $\mathrm{C}^{*}$ & $29.9 \pm 3.5^{\mathrm{a}}$ & $27.7 \pm 2.8^{\mathrm{abA}}$ & $26.7 \pm 1.8^{a b c B}$ & $22.8 \pm 4.0^{\mathrm{cB}}$ & $24.8 \pm 1.9 \mathrm{bcA}$ & $27.6 \pm 4.1^{\mathrm{bcA}}$ \\
\hline \multicolumn{7}{|c|}{$60^{\circ} \mathrm{C}$} \\
\hline$L^{*}$ & $43.5 \pm 3.5^{\mathrm{aB}}$ & $43.2 \pm 4.8^{\mathrm{aAB}}$ & $43.1 \pm 2.7^{\mathrm{aA}}$ & $39.8 \pm 2.4^{\mathrm{aA}}$ & $40.6 \pm 2.5^{\mathrm{aA}}$ & $39.7 \pm 4.3^{\mathrm{aB}}$ \\
\hline$h^{\circ}$ & $77.4 \pm 2.1^{\mathrm{aB}}$ & $78.4 \pm 1.3^{\mathrm{aB}}$ & $78.4 \pm 1.1^{\mathrm{aA}}$ & $78.5 \pm 1.9 \mathrm{aA}$ & $78.3 \pm 2.7^{\mathrm{aA}}$ & $78.0 \pm 2.2^{\mathrm{aA}}$ \\
\hline$C^{*}$ & $29.3 \pm 2.4^{\mathrm{aA}}$ & $27.7 \pm 3.9 \mathrm{abA}$ & $25.4 \pm 1.9$ abB & $24.7 \pm 2.4^{\mathrm{bAB}}$ & $24.6 \pm 2.3^{\mathrm{bA}}$ & $24.5 \pm 4.7^{\mathrm{bB}}$ \\
\hline \multicolumn{7}{|c|}{$70^{\circ} \mathrm{C}$} \\
\hline$L^{*}$ & $43.3 \pm 5.8^{\mathrm{aB}}$ & $42.5 \pm 2.2^{\mathrm{aB}}$ & $42.7 \pm 2.3^{\mathrm{aA}}$ & $39.5 \pm 2.2^{\mathrm{abA}}$ & $36.9 \pm 1.8^{b B}$ & $42.8 \pm 3.2^{\mathrm{aA}}$ \\
\hline$h^{\circ}$ & $77.4 \pm 1.5^{\mathrm{aB}}$ & $78.9 \pm 1.3^{\mathrm{aB}}$ & $77.3 \pm 1.8^{\mathrm{aA}}$ & $77.2 \pm 1.3^{\mathrm{aA}}$ & $77.7 \pm 1.9^{\mathrm{aA}}$ & $78.2 \pm 2.5^{\mathrm{aA}}$ \\
\hline$C^{*}$ & $29.8 \pm 3.9^{\mathrm{aA}}$ & $26.4 \pm 3.8^{\mathrm{abA}}$ & $28.5 \pm 1.7^{\mathrm{aA}}$ & $25.9 \pm 2.3^{\mathrm{abA}}$ & $22.8 \pm 1.2^{b B}$ & $28.9 \pm 4.1^{\mathrm{aA}}$ \\
\hline
\end{tabular}

Different lowercase letters in rows indicate significant differences $(p<0.05)$ between all considered samples at each drying temperature, while capital letters in columns indicate significant differences $(p<0.05)$ at the three drying temperatures.

\subsection{Total Polyphenols}

Total polyphenols contents in kiwifruit dried snacks are shown in Figure 1. The highest content of TP (2058 mg GAE/100 g dry matter $(\mathrm{dm})$ ) was observed in the $\mathrm{C}$ kiwifruit snack dried at $60{ }^{\circ} \mathrm{C}$, followed by the samples treated with $\mathrm{OD}$ and dried at the same temperature of $60^{\circ} \mathrm{C}(1311 \mathrm{mg} \mathrm{GAE} / 100 \mathrm{~g} \mathrm{dm})$. PEF pre-treatment of kiwifruit slices alone or in combination with OD promoted a significant decrease in TP values, showing the lowest values in samples dried at $60{ }^{\circ} \mathrm{C}$ which is an opposite trend to the one observed in $\mathrm{C}$ and OD samples. Finally, the snack pre-treated with PEF, OD and PEF again (PEF/OD/PEF) seems to not undergo variations in polyphenols among the different used drying temperatures, showing, however, the lowest TP values in comparison to the other treated samples. Regarding the temperature applied during the drying process, the highest retention of TP was observed for $\mathrm{C}$ samples, respectively, at 50 and $60^{\circ} \mathrm{C}$ and for the $\mathrm{OD}$ one dried at $70^{\circ} \mathrm{C}$, although long drying times were recorded at the lowest temperatures (respectively 960, 480 and $240 \mathrm{~min}$ ). 


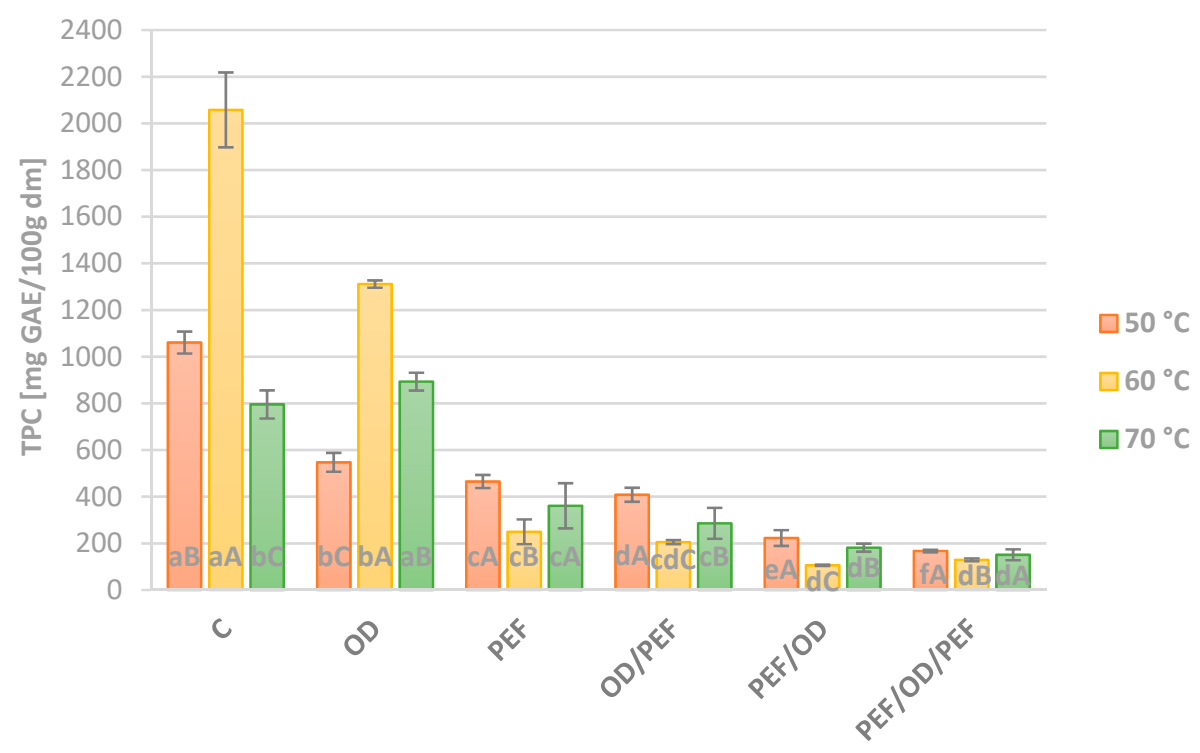

Figure 1. Total polyphenol content (TPC) of untreated and differently pre-treated kiwifruit snacks dried at the temperatures of 50,60 and $70{ }^{\circ} \mathrm{C}$. Different lowercase letters indicate significant differences $(p<0.05)$ between all considered samples at each drying temperature, while capital letters indicate significant differences $(p<0.05)$ between each sample at the three drying temperatures.

\subsection{Vitamin C Content}

The vitamin C contents of differently pre-treated kiwifruit chips dried at different temperatures are shown in Figure 2. The highest vitamin $C$ content was observed in $C$ kiwifruit slices dried at all the used temperatures and on OD and PEF pre-tretaed snacks dried at 70 and $50{ }^{\circ} \mathrm{C}$, respectively. The vitamin $\mathrm{C}$ content was strongly influenced by the pre-treatment applied on the kiwifruit chips. In fact, it decreased as the number of processing steps increased (from 46.48 to $21.82 \mathrm{mg}$ ascorbic acid/100 $\mathrm{g} \mathrm{dm}$ for OD and $\mathrm{PEF} / \mathrm{OD} / \mathrm{PEF}$ treated samples, respecively, dried at $50^{\circ} \mathrm{C}$ ). Except for sample PEF, in general, a better retention of vitamin $C$ was observed with an increase in the temperature (e.g., from 21.63 to $29.27 \mathrm{mg}$ ascorbic acid/100 $\mathrm{g} \mathrm{dm}$ for $\mathrm{PEF} / \mathrm{OD}$ chips dried at 50 and $70{ }^{\circ} \mathrm{C}$, respectively).

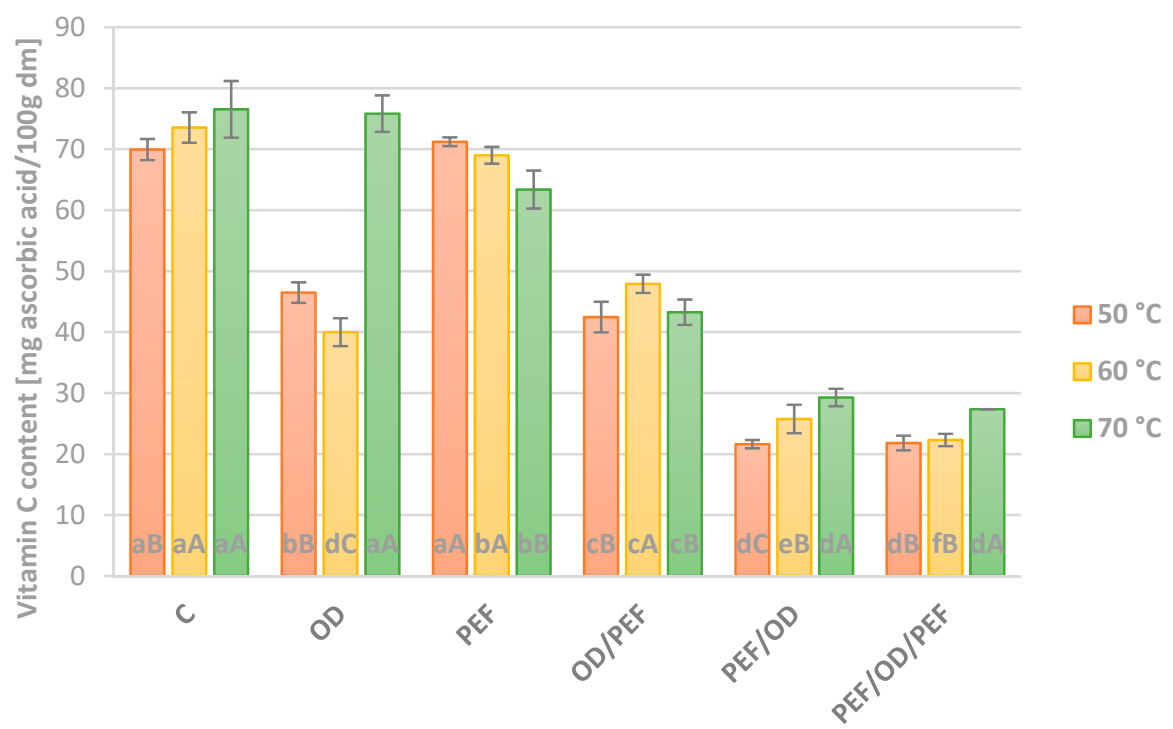

Figure 2. Vitamin $C$ content of untreated and differently pre-treated kiwifruit snacks dried at the temperatures of 50,60 and $70{ }^{\circ} \mathrm{C}$. Different lowercase letters indicate significant differences $(p<0.05)$ between all considered samples at each drying temperature, while capital letters indicate significant differences $(p<0.05)$ between each sample at the three drying temperatures. 


\subsection{Antioxidant Activity (DPPH and ABTS Assay)}

The antioxidant activity (AA) values measured by both DPPH and ABTS methods on differently obtained kiwifruit chips samples are shown in Figures 3 and 4, respectively. The behavior of the antiradical activity in all obtained samples is strongly dependent on both the explored pre-drying treatments and their combinations and on the applied drying temperature. The highest retention of bioactive compounds with the DPPH method (Figure 3) was observed in the $\mathrm{C}$ sample dried at $60{ }^{\circ} \mathrm{C}$, followed by the OD sample treated at the same temperature. PEF treatment alone and OD/PEF also showed a moderate antiradical DPPH activity, especially when the pre-treated kiwifruit chips were subsequently treated at the highest temperature of $70^{\circ} \mathrm{C}$. However, chips treated with PEF/OD and PEF/OD/PEF, independently of the drying temperature used, had a significantly lower AA in comparison with other kiwifruit samples. In particular, the lowest scavenging activity was observed in $\mathrm{PEF} / \mathrm{OD}$ and PEF/OD/PEF respectively dried at 70 and $60^{\circ} \mathrm{C}$ (589 and $538 \mu$ molTrolox/100 $\mathrm{g} \mathrm{dm}$ ).

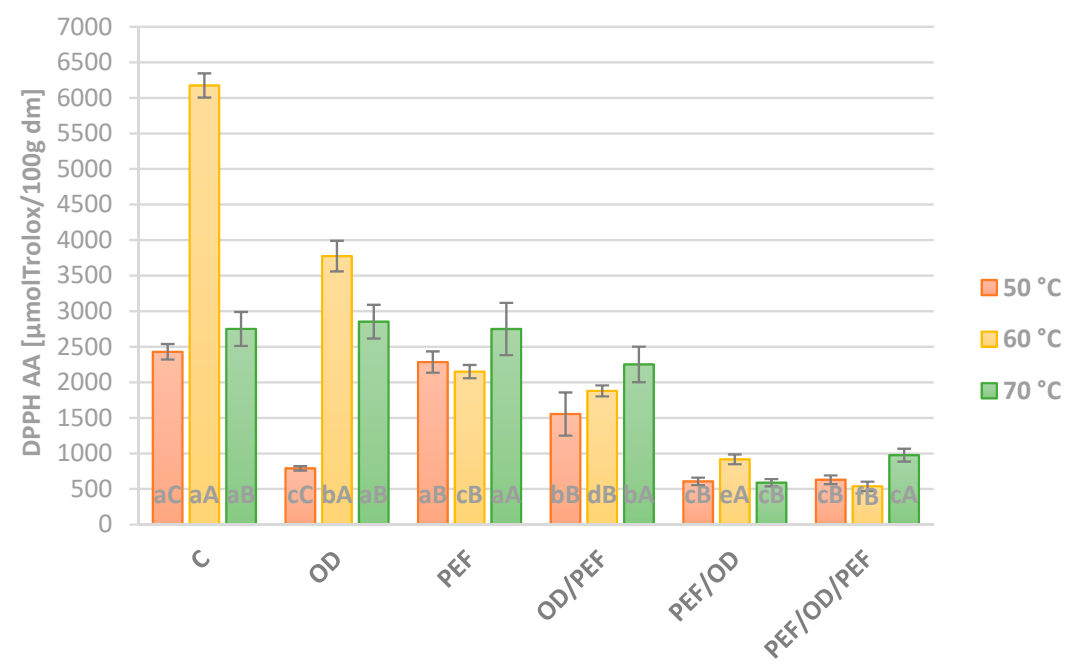

Figure 3. Antioxidant activity (AA) by DPPH assay of untreated and differently pre-treated kiwifruit snacks dried at the temperatures of 50,60 and $70{ }^{\circ} \mathrm{C}$. Different lowercase letters indicate significant differences $(p<0.05)$ between all considered samples at each drying temperature, while capital letters indicate significant differences $(p<0.05)$ between each sample at the three drying temperatures.

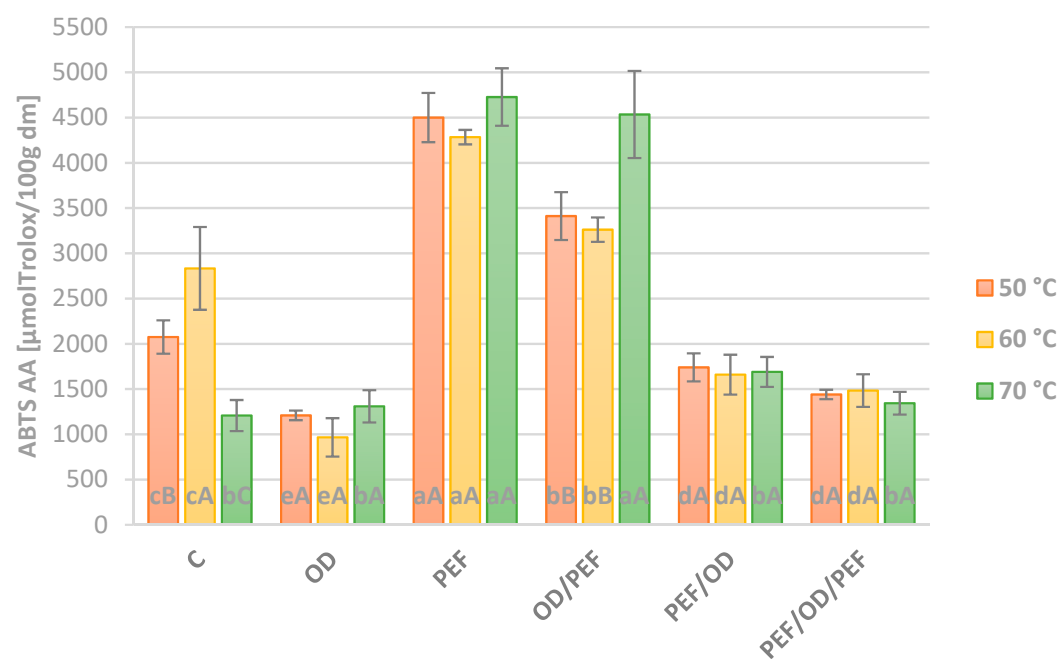

Figure 4. Antioxidant activity (AA) by ABTS assay of untreated and differently pre-treated kiwifruit snacks dried at the temperatures of 50,60 and $70{ }^{\circ} \mathrm{C}$. Different lowercase letters indicate significant differences $(p<0.05)$ between all considered samples at each drying temperature, while capital letters indicate significant differences $(p<0.05)$ between each sample at the three drying temperatures. 
However, AA measured with the ABTS method (Figure 4) showed the highest values, from 3261 to $4727 \mu$ molTrolox/100 $\mathrm{g} \mathrm{dm}$, in PEF and OD/PEF kiwifruit samples dried at all three drying temperatures. Conversely, the lowest values were observed for OD chips dried at 50 and $60^{\circ} \mathrm{C}$ and for $\mathrm{C}, \mathrm{OD}, \mathrm{PEF} / \mathrm{OD}$ and PEF/OD/PEF kiwifruit samples dried at $70{ }^{\circ} \mathrm{C}$.

\section{Discussion}

It has been reported in the literature that different pre-treatments could have an influence on the color parameters of the treated products. Tylewicz et al. [24] showed an increase in the luminosity $\left(L^{*}\right)$ of kiwifruit samples treated with OD in trehalose solution, while no differences were observed when sucrose was used in the osmotic solution. Similarly, the PEF pre-treatment alone resulted in significant changes in the color parameters of kiwifruit samples [25]. However, in the present work, the effect of the pre-treatment was evaluated only in the combination with the drying process and did not show any statistical differences. The decrease in luminosity observed in the kiwifruit snack samples pre-treated with the combination of $\mathrm{OD} / \mathrm{PEF}$ and $\mathrm{PEF} / \mathrm{OD}$ and dried at 50 and $70{ }^{\circ} \mathrm{C}$ could be due to the increased release of enzymes, such as peroxidase (POD) and polyphenoloxidase (PPO), and their substrates induced by the electroporation of the cell membrane [26] and by the leaching of pigments during osmotic dehydration [26]. Moreover, those samples also presented lower chroma parameter $\left(C^{*}\right)$ values which indicates a loss of color intensity. The drying temperature of $60{ }^{\circ} \mathrm{C}$ seems to be the most suitable for the maintenance of the kiwifruit fresh-like color. However, the color differences between the various samples, although significant in certain cases, do not indicate a negative effect of any of the applied treatments.

Fruits and vegetables are good sources of natural antioxidants, containing carotenoids, vitamins, phenolic compounds, folate and flavonoids. One of the reasons why kiwifruit is widely appreciated by consumers is related to its high nutritional quality.

Polyphenols are compounds which can influence the characteristics of plant materials, including color, bitterness and antioxidant activity [27].

Raw kiwifruit from the Jintao cultivar is particularly rich in polyphenols and, according to the literature, presents a value of TPC ranging from 139.5 to $143.8 \mathrm{mg} \mathrm{GAE} / 100 \mathrm{~g}$ [28].

As previously summarized, both pre-treatments and temperatures applied in this work had a negative effect on TPC except for the kiwifruit chips exposed to the OD treatment and dried at $60^{\circ} \mathrm{C}$. In particular, it appears that PEF alone and in combination with OD as well as thermal treatment could influence the PPO activity by enhancing its reaction with polyphenols and oxygen, which involves the oxidative degradation of phenolic compounds as explained by Yu et al. [29]. Conversely, higher TPC was observed for dried goji berries pre-treated with the combination of PEF (at different field strengths of $0.9,1.8$ and $2.8 \mathrm{kV} / \mathrm{cm}$ ) and $\mathrm{OD}\left(60 \mathrm{~min}\right.$ at $55^{\circ} \mathrm{C}$ in a hypertonic multi-component solution) processes when decreasing the drying time at $60^{\circ} \mathrm{C}$ [15].

Yu et al. [29] reported a loss in TP of around $48.8 \%$ for blueberries pre-treated with PEF at $3 \mathrm{kV} / \mathrm{cm}$, with 200 pulses per second, a pulse width of $1 \mu$ s and total treatment time of 5 min subsequently subjected to the OD process (fruit/syrup ratio of 1:2 at $40{ }^{\circ} \mathrm{C}$ ), without further drying.

Kiwifruit is rich in vitamin C, which represents the prevalent nutritional compound in this type of fruit; indeed, it accounts for about 130 to $170 \mathrm{mg} / 100 \mathrm{~g}$ and 68 to $104 \mathrm{mg} / 100 \mathrm{~g}$, respectively, in Jintao and Hayward cultivars at the harvest time [30]. Moreover, vitamin $C$ is a compound sensitive to oxidative reactions, which may be triggered by the high temperature and the presence of oxygen, so for this reason, it can be considered as an indicator of the overall quality of this kind of fruit during processing.

It is stated from the literature that the increasing drying temperature and time provoke a decrease in vitamin C content in different types of fruit [31-33]. On the contrary, in the present study, in most of the samples with the increasing drying temperature, a higher vitamin $C$ content was observed; this result could be due to the reduced treatment time (necessary to reach $\mathrm{a}_{\mathrm{w}}=0.2$ ) and thus to a shorter exposure to the highest temperature. Moreover, the lower number of processing steps such as in the case of the control sample (C) or of those subjected to a single pre-treatment (OD and PEF samples) 
allowed a better retention of vitamin $C$ and probably even other valuable compounds. In fact, OD and PEF kiwifruit chips dried, respectively, at 70 and $50{ }^{\circ} \mathrm{C}$ showed ascorbic acid values significantly similar to those of $C$ samples.

These results clearly showed that the number of processing steps together with an oxygen-rich environment could significantly reduce the ascorbic acid content.

The AA, assessed with both DPPH and ABTS methods, revealed different results owing to the different capabilities of the two assays to detect certain valuable components. In fact, DPPH is more prone to identify flavonoids compounds, while the ABTS method seems to be more suitable for vitamin C [34].

Indeed, a higher retention of bioactive compounds by the DPPH assay was observed for $\mathrm{C}$ and OD chips dried at $60^{\circ} \mathrm{C}$, which is in line with the TPC results observed in the same dried samples ( $\mathrm{R}^{2}$ of 0.77 and 0.70 , respectively). The AA results obtained with the ABTS method were higher in the kiwifruit chips pre-treated only with PEF and dried at all three temperatures and with the combination of PEF/OD after drying at $70^{\circ} \mathrm{C}$. These findings were not affected by the observed values of vitamin $\mathrm{C}$ content, expect for the PEF-treated chips dried at $50^{\circ} \mathrm{C}\left(\mathrm{R}^{2}\right.$ of 0.70$)$.

Moreover, the changes in the cellular membranes may have induced a greater release of bounded antioxidant compounds, making them more accessible during the extraction step before the assays of both methods. Similar results were reported by [16], who investigated the application of PEF $(2.8 \mathrm{kV} / \mathrm{cm}$, 750 pulses $)$ and $\mathrm{OD}\left(55^{\circ} \mathrm{C}, 60 \mathrm{~min}\right)$ prior to the drying process at $60^{\circ} \mathrm{C}$ in a goji berry product.

Huang et al. [35] reported a high retention of bioactive compounds assessed by the DPPH method in apricot pre-treated with PEF (at $1.25 \mathrm{kV} / \mathrm{cm}, 30 \mathrm{~s}, 100 \mathrm{~Hz}$ and pulse width of $20 \mu \mathrm{s}$ ) and subsequently subjected to soaking in a $0.2 \%$ sodium sulfite solution (fruit/solution ratio of $2: 5$ ) for $1 \mathrm{~h}$ and finally hot air-dried at $45^{\circ} \mathrm{C}$.

As for the intensity of the PEF treatment, Tylewicz et al. [24] observed a significant increase, around $15.7 \%$, in the antioxidant activity assessed by DPPH in strawberry tissues treated at $200 \mathrm{~V} / \mathrm{cm}$ and $10 \mu \mathrm{s}$ (total treatment time of $10 \mathrm{~s}$ and specific energy of $1.92 \mathrm{~kJ} / \mathrm{kg}$ ), while for kiwifruits, lower intensities of PEF $(100 \mathrm{~V} / \mathrm{cm}, 0.96 \mathrm{~kJ} / \mathrm{kg})$ were found more beneficial on the retention of antioxidant compounds (7\%). However, the combination of PEF at 100 and $200 \mathrm{~V} / \mathrm{cm}$ and OD with trehalose solution (40\%) caused lower antioxidant activity in both strawberry and kiwifruit samples compared to related untreated tissues.

The application of different pre-treatments caused a reduction in the drying time. This reduction was higher when the lowest temperature of $50{ }^{\circ} \mathrm{C}$ was used (62-68\%), while for the samples dried at 60 and $70{ }^{\circ} \mathrm{C}$, the reduction in drying time was of $25-50 \%$ and $28-57 \%$, respectively. A reduction in drying times of 30-60\% was also observed by Osae et al. [36] and Bialik et al. [37], respectively, for ginger slices and kiwiberry. Moreover, OD treatment can reduce the total energy consumption (two-three times) if compared to convective drying without any pre-treatment [38]. Similarly, PEF pre-treatment, due to the electroporation that takes place in the whole treated product, can also cause the enhancement of mass transfer and consequently a reduction in the drying time $[15,16]$. Thus, the reduction in the process time, especially for the lower drying temperature, for both the OD and PEF pre-treatments would bring a significant reduction in the total request of energy even considering the energy input for the PEF treatment $(1.92 \mathrm{~kJ} / \mathrm{kg}$ in our experiments), meaning that it could be an important contribution to improve the process sustainability as a "greener" drying process. Regarding the water consumption involved in the OD pre-treatment, it can be considered negligible since it uses a hypertonic solution, which could easily be recycled [39]. However, accurate computation of all the energy and water demand factors should be clarified in future research (e.g., throughout life cycle assessment approach) to better understand the process's environmental impact. Moreover, the aforementioned "green" food pre-processing contributes to design a renewable natural product with valuable quality features through the reuse of industrial food waste. 


\section{Conclusions}

The obtained results showed that OD pre-treatment applied alone resulted in a good retention of TPC and AA measured by the DPPH method, while PEF treatment alone showed a high content of vitamin $C$ and AA assessed by the ABTS method. In both samples, the values were similar to those of control samples. However, the shortest drying times required for the OD and PEF pre-treated samples could have an additional positive effect on the sustainability of the overall process, by saving the energy required for the process. In general, an increased number of processing steps had a negative influence on the retention of the bioactive compounds and on the antiradical activity in all samples, while the color differences among them, although significant in certain cases, did not indicate a negative effect of any treatment.

In order to possibly scale-up the applied single/combined processing steps in a real industrial scenario, a further study is necessary considering both the energy and managing costs and the stability and nutritional quality of the obtained products, particularly in terms of environmental and economic sustainability.

\section{Basic Mechanisms of the Pre-Treatments Applied}

Drying is a technology widely used to obtain shelf-stable food products and snacks. However, drying is a time- and energy-consuming process, therefore the application of pre-treatments such as pulsed electric field (PEF) and osmotic dehydration (OD) alone or in combination could be important both for energy saving and preservation of the final food quality.

PEF technology consists in the application of pulses of high voltage and short duration (ms- $\mu \mathrm{s}-\mathrm{ns})$ to a biological material placed between two electrodes. The application of the external electric field (Ee) to the biological material promotes the electroporation of the tissue, which could be of different extents, reversible or irreversible, as it is shown in Figure 5. When the applied electric field strength (Ee) exceeds a critical value $(\mathrm{Ee}>\mathrm{Ec}$ ), a temporary membrane permeabilization takes place. However, if the electric field is still below the irreversible electroporation threshold, cells can recover their integrity and remain viable after the electric field exposure. The reversible electroporation (the created pores reseal immediately after removing the electrical field) could be used to incorporate different functional substances into the vegetal tissue, ensuring the survival of the electrically stimulated cells. On the other hand, when the electric field strength greatly exceeds Ec values (Ee $>>\mathrm{Ec}$ ), a permanent membrane permeabilization takes place. This phenomenon leads to extensive leakage of the intracellular content and cell death, which find wild applications in the microbial inactivation of liquid foods and for the cell disintegration of biological tissues [40].

Electroporation and, consequently, cell disintegration of biological tissues upon the application of a low/moderate electric field strength $(0.1-5 \mathrm{kV} / \mathrm{cm})$ can be used for the enhancement of mass and heat-based processes of structure modification [41].

Osmotic dehydration is a partial dewatering impregnation process, usually carried out by immersion of a cellular tissue, which is characterized by semipermeable membranes, in hypertonic solution. Thanks to the differences in the water chemical potential between the tissue and the osmotic solution, an important mass transfer phenomenon can occur (Figure 5). There is a water loss from the tissue into the osmotic solution, while at the same time, there is a simultaneous counter-diffusion of solutes from the concentrated solution into the tissue. During osmotic dehydration, the membrane responsible for osmotic transport progressively loses its selectivity, therefore a leakage of the natural solutes present in the cells (e.g., vitamins, pigments) can also occur [42].

Osmotic dehydration can be used as a pre-treatment for fruit and vegetables intended for further processing, like, for example, drying, contributing to the reduction in the drying time [43]. 


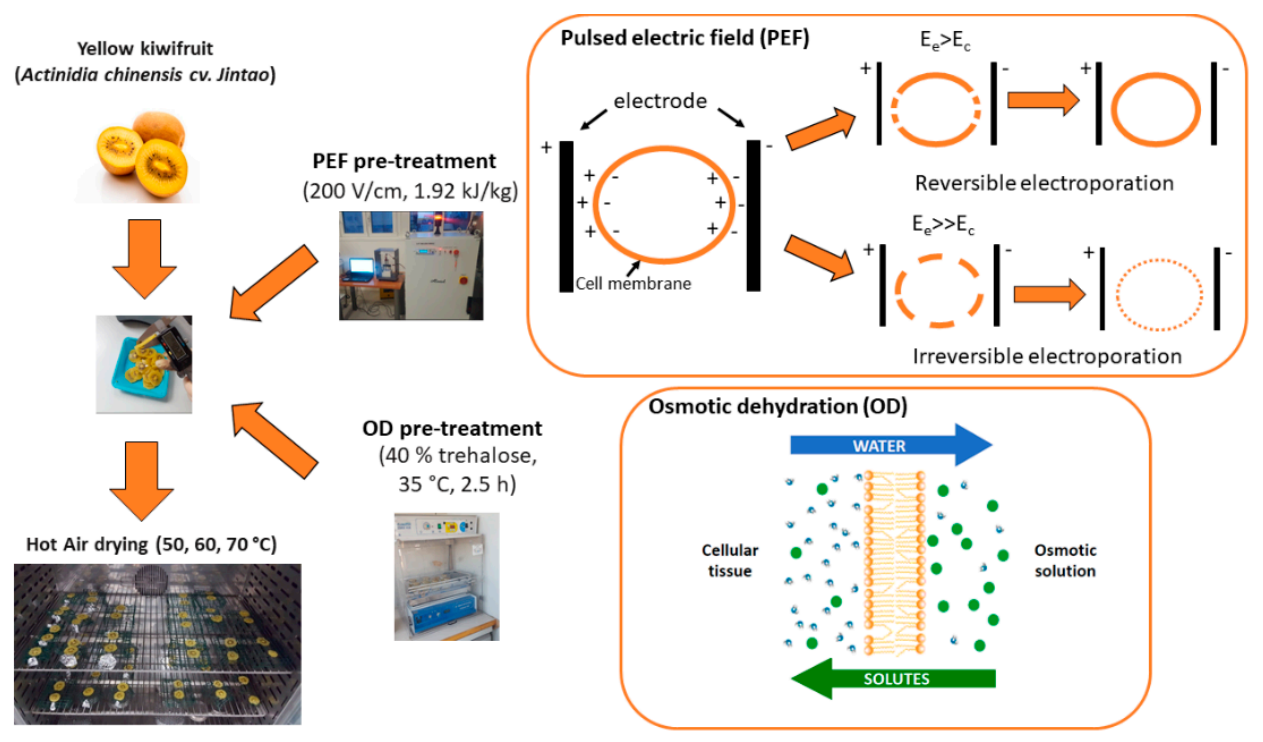

Figure 5. Application of pulsed electric field (PEF) and osmotic dehydration (OD) as a pre-treatment before hot air drying-mechanism of action.

Author Contributions: Conceptualization, C.M., U.T. and M.D.R.; methodology, C.M., U.T. and S.T.; software, C.M. and U.T.; validation, C.M., U.T. and S.T.; formal analysis, C.M.; investigation, C.M. and U.T.; resources, M.D.R.; data curation, C.M. and U.T.; writing-original draft preparation, C.M. and U.T.; writing-review and editing, C.M., U.T., S.T., M.D.R., P.R. and S.R.; visualization, C.M., U.T.; supervision, P.R. and S.R.; project administration, M.D.R.; funding acquisition, M.D.R. All authors have read and agreed to the published version of the manuscript.

Funding: Support for this project was provided by Emilia-Romagna Region within the PSR 2014-2020 Project (Focus Area 5 C).

Conflicts of Interest: The authors declare no conflict of interest.

\section{References}

1. Betoret, E.; Betoret, N.; Vidal, D.; Fito, P. Functional foods development: Trends and technologies. Trends Food Sci. Technol. 2011, 22, 498-508. [CrossRef]

2. Meynard, J.M.; Jeuffroy, M.H.; Le Bail, M.; Lefèvre, A.; Magrini, M.B.; Michon, C. Designing coupled innovations for the sustainability transition of agrifood systems. Agric. Syst. 2017, 157, 330-339. [CrossRef]

3. Woodhouse, A.; Davis, J.; Pénicaud, C.; Östergren, K. Sustainability checklist in support of the design of food processing. Sustain. Prod. Consum. 2018, 16, 110-120. [CrossRef]

4. Sagar, N.A.; Pareek, S.; Sharma, S.; Yahia, E.M.; Lobo, M.G. Fruit and Vegetable Waste: Bioactive Compounds, Their Extraction, and Possible Utilization. Compr. Rev. Food Sci. Food Saf. 2018, 17, 521-531. [CrossRef]

5. The Publications Office of the European Union. COMMISSION REGULATION (EC) No 1673/2004 of 24 September 2004 Laying Down the Marketing Standard Applicable to Kiwifruit; The Publications Office of the European Union: Luxembourg, 2004; pp. 5-10.

6. Ma, T.; Sun, X.; Zhao, J.; You, Y.; Lei, Y.; Gao, G.; Zhan, J. Nutrient compositions and antioxidant capacity of kiwifruit (Actinidia) and their relationship with flesh color and commercial value. Food Chem. 2017, 218, 294-304. [CrossRef] [PubMed]

7. Amami, E.; Khezami, L.; Vorobiev, E.; Kechaou, N. Effect of pulsed electric field and osmotic dehydration pretreatment on the convective drying of carrot tissue. Dry. Technol. 2018, 26, 231-238. [CrossRef]

8. Tylewicz, U.; Nowacka, M.; Rybak, K.; Drozdzal, K.; Dalla Rosa, M.; Mozzon, M. Design of Healthy Snack Based on Kiwifruit. Molecules 2020, 25, 3309. [CrossRef]

9. Aguilera, J.M.; Chiralt, A.; Fito, P. Food dehydration and product structure. Trends Food Sci. Technol. 2003, 14, 432-437. [CrossRef]

10. Chou, S.K.; Chua, K.J. New hybrid drying technologies for heat sensitive foodstuffs. Trends Food Sci. Technol. 2001, 12, 359-369. [CrossRef] 
11. Tylewicz, U.; Tappi, S.; Mannozzi, C.; Romani, S.; Dellarosa, N.; Laghi, L.; Ragni, L.; Rocculi, P.; Dalla Rosa, M. Effect of pulsed electric field (PEF) pre-treatment coupled with osmotic dehydration on physico-chemical characteristics of organic strawberries. J. Food Eng. 2017, 213, 2-9. [CrossRef]

12. Dermesonlouoglou, E.; Zachariou, I.; Andreou, V.; Taoukis, P.S. Effect of pulsed electric fields on mass transfer and quality of osmotically dehydrated kiwifruit. Food Bioprod. Process. 2016, 100, 535-544. [CrossRef]

13. Thamkaev, G.; Gómez Galindo, F. Influence of pulsed and moderate electric field protocols on the reversible permeabilization and drying of Thai basil leaves. Innov. Food Sci. Emerg. Technol. 2020. [CrossRef]

14. Wiktor, A.; Dadan, M.; Nowacka, M.; Rybak, K.; Witrowa-Rajchert, D. The impact of combination of pulsed electric field and ultrasound treatment on air drying kinetics and quality of carrot tissue. LWT-Food Sci. Technol. 2019, 110, 71-79. [CrossRef]

15. Wiktor, A.; Nowacka, M.; Dadan, M.; Rybak, K.; Lojkowski, W.; Chudoba, T.; Witrowa-Rajchert, D. The effect of pulsed electric field on drying kinetics, color, and microstructure of carrot. Dry. Technol. 2016, 34, 1286-1296. [CrossRef]

16. Dermesonlouoglou, E.; Chalkia, A.; Dimopoulos, G.; Taoukis, P. Combined effect of pulsed electric field and osmotic dehydration pre-treatments on mass transfer and quality of air dried goji berry. Innov. Food Sci. Emerg. Technol. 2018, 49, 106-115. [CrossRef]

17. Khan, M.R. Osmotic dehydration technique for fruits preservation-A review. Pak. J. Food Sci. 2012, 22, 71-85.

18. Crowe, J.H.; Crowe, L.M.; Oliver, A.E.; Tsvetkova, N.; Wolkers, W.; Tablin, F. The trehalose myth revisited. Introduction to a symposium on stabilization of cells in the dry state. Cryobiology 2001, 43, 89-105. [CrossRef]

19. Galmarini, M.V.; Schebor, C.; Zamora, M.C.; Chirife, J. The effect of trehalose, sucrose and maltodextrin addition on physicochemical and sensory aspects of freeze-Dried strawberry puree. IJFST 2009, 44, 1869-1876. [CrossRef]

20. Tylewicz, U.; Mannozzi, C.; Romani, S.; Castagnini, J.M.; Samborska, K.; Rocculi, P.; Dalla Rosa, M. Chemical and physicochemical properties of semi-dried organic strawberries enriched with bilberry juice-based solution. LWT-Food Sci. Technol. 2019, 114, 108377. [CrossRef]

21. Ciancaglini, P.; Santos, H.L.; Daghastanli, K.R.P.; Thedei, G., Jr. Using a Classical Method of Vitamin C Quantification as a Tool for Discussion of Its Role in the Body. Biochem. Mol. Biol. Edu. 2001, 29, 110-114. [CrossRef]

22. Amarowicz, R.; Naczk, M.; Shahidi, F. Antioxidant activity of various fractions of non-tannin phenolics of canola hulls. J. Agric. Food Chem. 2000, 48, 2755-2759. [CrossRef]

23. Re, R.; Pellegrini, N.; Proteggente, A.; Pannala, A.; Yang, M.; Rice-Evans, C. Antioxidant activity applying an improved ABTS radical cation decolorization assay. Free Radic. Biol. Med. 1999, 26, 1231-1237. [CrossRef]

24. Tylewicz, U.; Oliveira, G.; Alminger, M.; Nohynek, L.; Dalla Rosa, M.; Romani, S. Antioxidant and antimicrobial properties of organic fruits subjected to PEF-assisted osmotic dehydration. Innov. Food Sci. Emerg. Technol. 2020, 102341. [CrossRef]

25. Wiktor, A.; Sledz, M.; Nowacka, M.; Rybak, K.; Chudoba, T.; Lojkowski, W.; Witrowa-Rajchert, D. The impact of pulsed electric field treatment on selected bioactive compound content and color of plant tissue. Innov. Food Sci. Emerg. Technol. 2015, 30, 69-78. [CrossRef]

26. Nowacka, M.; Tylewicz, U.; Romani, S.; Dalla Rosa, M.; Witrowa-Rajchert, D. Influence of ultrasound-assisted osmotic dehydration on the main quality parameters of kiwifruit. Innov. Food Sci. Emerg. Technol. 2017, 41,71-78. [CrossRef]

27. Silva, A.M.; Pinto, D.; Fernandes, I.; Gonçalves Albuquerque, T.; Costa, H.S.; Freitas, V.; Rodrigues, F.; Oliveira, M.B.P.P. Infusions and decoctions of dehydrated fruits of Actinidia arguta and Actinidia deliciosa: Bioactivity, radical scavenging activity and effects on cells viability. Food Chem. 2019, 289, 625-634. [CrossRef]

28. Zhang, H.; Zhao, Q.; Lan, T.; Geng, T.; Gao, C.; Yuan, Q.; Zhang, Q.; Xu, P.; Sun, X.; Liu, X.; et al. Comparative Analysis of Physicochemical Characteristics, Nutritional and Functional Components and Antioxidant Capacity of Fifteen Kiwifruit (Actinidia) Cultivars-Comparative Analysis of Fifteen Kiwifruit (Actinidia) Cultivars. Foods 2020, 9, 1267. [CrossRef]

29. Yu, Y.; Jin, T.Z.; Fan, X.; Wu, J. Biochemical degradation and physical migration of polyphenolic compounds in osmotic dehydrated blueberries with pulsed electric field and thermal pretreatments. Food Chem. 2018, 239, 1219-1225. [CrossRef]

30. Huang, H.; Wang, S.; Huang, R.; Jiang, Z.; Zhang, Z. 'Jintao', a novel, hairless, yellow-fleshed kiwifruit. HortScience 2002, 37, 1135-1136. [CrossRef] 
31. Piga, A.; Del Caro, A.; Corda, G. From plums to prunes: Influence of drying parameters on polyphenols and antioxidant activity. J. Agric. Food Chem. 2003, 51, 3675-3681. [CrossRef]

32. Gamboa-Santosa, J.; Megías-Pérez, R.; Soria, A.C.; Olano, A.; Montilla, A.; Villamiel, M. Impact of processing conditions on the kinetic of vitamin $\mathrm{C}$ degradation and 2-furoylmethyl amino acid formation in dried strawberries. Food Chem. 2014, 153, 164-170. [CrossRef]

33. Bozkir, H. Effects of hot air, vacuum infrared, and vacuum microwave dryers on the drying kinetics and quality characteristics of orange slices. J. Food Process Eng. 2020, e13485. [CrossRef]

34. Del Caro, A.; Piga, A.; Vacca, V.; Agabbio, M. Changes of flavonoids, vitamin C and antioxidant capacity in minimally processed citrus segments and juices during storage. Food Chem. 2004, 84, 99-105. [CrossRef]

35. Huang, W.; Feng, Z.; Aila, R.; Hou, Y.; Carne, A.; Bekhit, A.E.D.A. Effect of pulsed electric fields (PEF) on physico-chemical properties, $\beta$-carotene and antioxidant activity of air-dried apricots. Food Chem. 2019, 291, 253-262. [CrossRef]

36. Osae, R.; Zhou, C.; Xu, B.; Tchabo, W.; Bonah, E.; Alenyorege, E.A.; Ma, H. Nonthermal pretreatments enhances drying kinetics and quality properties of dried ginger (Zingiber officinale Roscoe) slices. J. Food Process. Eng. 2019, 42. [CrossRef]

37. Bialik, M.; Wiktor, A.; Witrowa-Rajchert, D.; Gondek, E. The Influence of Osmotic Dehydration Conditions on Drying Kinetics and Total Carotenoid Content of Kiwiberry (Actinidia Arguta). IJFE 2020, 16, 20180328. [CrossRef]

38. Lenart, A.; Lewicki, P.P. Energy consumption during osmotic and convective drying of plant tissue. Acta Aliment. Pol. 1988, 1, 65-72.

39. Dalla Rosa, M.; Giroux, F. Osmotic treatments (OT) and problems related to the solution management. J. Food Eng. 2001, 49, 223-236. [CrossRef]

40. Tylewicz, U. How does pulsed electric field work? In Pulsed Electric Fields to Obtain Healthier and Sustainable Food for Tomorrow; Barba, F.J., Parniakov, O., Wiktor, A., Eds.; Elsevier: Cambridge, MA, USA, 2020; pp. 3-21.

41. Donsì, F.; Ferrari, G.; Pataro, G. Applications of pulsed electric field treatments for the enhancement of mass transfer from vegetable tissue. Food Eng. Rev. 2010, 2, 109-130. [CrossRef]

42. Tylewicz, U.; Panarese, V.; Laghi, L.; Rocculi, P.; Nowacka, M.; Placucci, G.; Dalla Rosa, M. NMR and DSC Water Study during Osmotic Dehydration of Actinidia deliciosa and A. chinensis kiwifruit. Food Biophys. 2011, 6, 327. [CrossRef]

43. Dermesonlouoglou, E.K.; Pantelaiaki, K.; Andreou, V.; Katsaros, G.J.; Taoukis, P.S. Osmotic pretreatment for the production of novel dehydrated tomatoes and cucumbers. J. Food Process. Preserv. 2019, 43, e13968. [CrossRef]

Publisher's Note: MDPI stays neutral with regard to jurisdictional claims in published maps and institutional affiliations.

(C) 2020 by the authors. Licensee MDPI, Basel, Switzerland. This article is an open access article distributed under the terms and conditions of the Creative Commons Attribution (CC BY) license (http://creativecommons.org/licenses/by/4.0/). 